\title{
Monitoring Selected Species of Mammals in Grand Teton National PARK IN 1999
}

\author{
BRIAN MILLER $\uparrow$ DENVER ZOO \\ DENVER $\uparrow \mathrm{CO}$ \\ HANK HARLOW $\downarrow$ DEPARTMENT. OF ZOOLOGY AND PHYSIOLOGY \\ UNIVERSITY OF WYOMING $\uparrow$ LARAMIE
}

\begin{abstract}
$\downarrow$ INTRODUCTION
Studies that investigate community relationships among mammals typically require large temporal and areal scales (Krebs et al. 1995; Estes 1996; Terborgh et al. 1999). Despite the difficulties presented by larger scales, such studies are valuable to decision-makers (Sinclair 1991; Smith et al. 1999). Understanding abundance, distribution, habitat choice, and ecological interactions of mammalian species can promote management decisions that benefit overall ecosystem health. Monitoring programs that build an ecological model of the landscape, and assess the trends in relation to biotic and abiotic changes, are essential to adaptive management, yet are seldom a standard part of management activities (Sinclair 1991; Noss and Cooperrider 1994; Lancia et al. 1996; Noss et al. 1996). Indeed, a conservation plan requires a longterm obligation to standardized ecological monitoring so that actions can be adjusted according to new information (Noss et al. 1996).
\end{abstract}

Over the long term, this standardized monitoring plan will provide information on small and medium-sized mammals that will (1) assess species use of habitat, (2) monitor changes in species composition as a result of environmental change, (3) produce predictive models of small and mediumsized mammal distribution based on vegetation type, and (4) analyze the impact of wolf (Canis lupus) colonization on the mammal (and plant) community. Such standardized monitoring techniques for mammal communities have not been done in the Greater Yellowstone Ecosystem.

The abundance and diversity of mammals can be greatly affected by a number of factors. These include plant productivity (Hunter and Price 1994; Krebs et al. 1995; Polis and Strong 1996), climate (Pinter 1996; Hoogland 1995; Post et al. 1999), natural disturbance (Pickett and White 1985), disease (Dobson and May 1986), and expected or unexpected environmental change (Lancia et al. 1996; Thompson et al. 1998).

Changes in numbers of large predators also affect the mammal community (Erlinge et al. 1984; 1988; Soulé et al. 1988; McLaren and Peterson 1994; Krebs et al. 1995; Estes 1996; Terborgh et al. 1997; 1999; Crooks and Soulé 1999; Henke and Bryant 1999). There is a growing body of experimental evidence indicating that top carnivores act as keystone species (see review by Terborgh et al. 1999), and the recent reintroduction of wolves to Yellowstone National Park may impact the plants and animals of the overall region. A long-term ecological research program that analyzes such interactions is "imperative" in the Greater Yellowstone Ecosystem (Smith et al. 1999, p. 121).

For example, the recent recolonization of wolves in the northern Midwest has restricted the distance that beavers (Castor canadensis) forage from aquatic habitats, and that reduces the impact of beaver on plant associations (Naiman et al. 1994, 
Pollock et al. 1995). The presence of wolves on Isle Royale, Michigan has also produced compelling evidence of a trophic cascade (McLaren and Peterson 1994; Messier 1994). Similarly, the re-establishment ofwolveshasbeenfollowed by declines in caribou (Rangifer tarandus), moose (Alces alces), elk (Cervus elephus), deer (Odocoileus hemionus), and coyotes (Canis latrans) (Bergerud 1988; Messier and Crête 1985; Hatter and Janz 1994; Crabtree and Sheldon 1999). Because there are known linkages among moose, microbes, and soil nutrients, the impact of predation affects abundance, diversity, and biomass of plants and animals on Isle Royale (Pastor et al. 1988; McClaren and Peterson 1994).

While the terms keystone species and topdown vs. bottom-up interactions may be slightly inelegant, and contentious as to matter of degree, it is crucial to try to understand the role of large carnivores in ecosystem health. If top predators play a role in maintaining the integrity of ecological communities, then managing them successfully will be critical. On the other hand, failure to understand the role of top predators, and to manage them accordingly, can result in distorted ecological interactions that will jeopardize biodiversity.

\section{$\downarrow$ METHODS}

Vegetation types in Grand Teton National Park (GTNP) followed the maps created by Debinski et al. (1996). Non-forested meadow classes, representing a distinct xeric-to-mesic gradient were identified in accordance with Debinski (1996). This gradient ranged from sedge meadow (M1) to dry grassland with sagebrush (M6). In addition, we identified forested plots predominantly consisting of lodgepole pine. During the summer we sampled plots representing the lodgepole pine forest and M1, M2, M3 and M6 meadow types. We sampled five different habitat types at the same altitude with one replicate in each habitat type. Next year we plan to expand to seven habitat types with two replicates at each site. The habitats we sampled in 1999 included lodgepole pine, dry sage, mixed grasses and forbs, sedge-grass damp meadow, and sedge-grass swamp.

We followed the standard capture-recapture techniques for small mammals (e.g. mice and voles, see Clark and Stromberg 1987) using folding Sherman traps that are $22.5 \mathrm{~cm}$ long and 7.5 by 7.5 $\mathrm{cm}$ wide. We marked rodents with ear tags purchased from National Band and Tag. This method was tested and all tags were retained on captive animals during a three-week trial. Bait was rolled oats that were coated with molasses.

We trapped a site continuously until recaptures roughly equal new captures. For this reason, the sampled area was considered a closed population (Caughley 1977; Lancia et al. 1996; Thompson et al. 1998). Abundance was calculated with several estimators, including Jolly Seber (Caughley 1977) and a regression slope based on capture per unit effort (Caughley 1977). In the future, we will employ program CAPTURE as well (White et al. 1982). Number of trap-nights was adjusted for sprung traps via the technique of Beauvais and Buskirk (1999).

The Jolly Seber method requires calculation of a population estimate on each successive night of trapping, but it offers no explicit solution for population samples that differ among the first and last trapping occasions (Caughley 1977). Rate of change between two occasions can be calculated by the method used in Bailey's triple catch analysis (Caughley 1977), but that method is designed for cases where individuals are born during the experiment, and our trapping occasions were only separated by one night. We therefore eliminated any estimates that were less than the actual number of individual animals trapped, and we reported the range and standard error of estimates.

The standard grid size was 1 hectare with two replicate grids at a site. Traps within a grid were spaced every 10 meters (121 traps per 1 ha grid). The population size associated with a grid is a function of two known factors (grid area and perimeter) and two unknown factors (boundary strip-width and true animal density) (Otis et al. 1978). So, when sample size allows, data for each grid are analyzed as a series of nested grids to address the issue of boundary stripwidth and make the population estimate more accurate (Otis et al. 1978; Lancia et al. 1996).

Species not easily seen or trapped were estimated via an index thought to be correlated with abundance (Lancia et al. 1996). For example, northern pocket gopher (Thomomys talpoides) were indexed by counting mounds within a 1 ha grid, and badgers (Taxidae taxus) by number of fresh digs (presence of fresh sub-soil on the mound that is not yet hardened by sun). Observers counted all sign within transects $100 \mathrm{~m}$ long and 5 meters until the entire one hectare grid was surveyed. 


\section{RESULTS AND DISCUSSION}

We began trapping with Sherman traps on 22 July, 1999, with a one hectare plot in dry sage (M6-Debinski et al. 1996) and a one hectare plot in lodgepole pine. The sage brush plot is located on Two Ocean Creek Road near the turn-off from Pacific Creek Road, and the UTMs are E 540754 and $\mathrm{N} 857228$. The lodgepole pine plot is located near Pacific Creek Road after the road changes from asphalt to gravel, and the UTMs are E 538872 and N 856774. Both plots were trapped through 1 August 1999.

On the dry sage plot (M6), we captured a total of 11 different Peromyscous maniculatus and four different Microtis spp. We suspect that three were $M$. montanus and one was $M$. pennsylvannicus, based on observations by A. Pinter that those two species have a different shape to their rumps. The method of determining species in the field, however, has not yet been verified, but we will test that technique next year with A. Pinter. P. maniculatus is a generalist found in a range of habitats except in very wet areas (Nowak 1991). M. montanus is generally found in drier habitats than $M$. pennsylvanicus (Nowak 1991).

In total, there were 1369 trap-nights, 15 captures and 15 recaptures. So trapping success was $2.2 \%$. All recaptures were of $P$. maniculatus. One male Microtis was found with fresh wounds on its hips and lower back. The wounds were in the region of the subcaudal scent glands, which may indicate a fight with another Microtis. Sex ratio of captured adult $P$. maniculatus was 2 females and 4 males.

Using Jolly Seber (Caughley 1977), we calculated an estimate of $17.5 \mathrm{P}$. maniculatus per hectare in dry sage habitat with a standard error of 19.3. Using the data to calculate a regression slope with capture of new animals per unit effort we calculated a population of $12 \mathrm{P}$. maniculatus per hectare of dry sage with a standard error of 1.16 ( $\mathrm{p} \leq$ 0.10 ). The last two nights of trapping produced 6 recaptures of $P$. maniculatus, but no new captures (over the trapping, there were 11 different deer mice captured). So, although sample-size is low, the regression and Jolly-Seber estimates seem to be a reasonable population estimate for $P$. maniculatus in the dry sage grid. Nowak (1991) reported that population densities for $P$. maniculatus range from 1 to 25 per ha.

We captured one adult male 4 times and a female and a juvenile female 7 times. Based on this small sample of locations, the adult male covered $1000 \mathrm{~m}^{2}$ and the female covered $524 \mathrm{~m}^{2}$. Nowak (1991) reported that home ranges can vary from .04 ha to 4 ha per individual and that the average is 1 ha for males and 0.6 ha for females.

When walking the one hectare plot to search for sign, we established the following data for indices: 30 pocket gopher winter casts, 15 fresh pocket gopher mounds, 166 mouse/vole holes, 60 piles of elk scat, 3 piles of deer scat, 1 moose scat, 1 bison (Bison bison) scat, 8 badger holes, 40 ant hills, 1 coyote scat, 25 carnivore scrapes at holes, and 2 ground squirrel holes.

On the lodgepole pine plot, we captured 13 different Clethrionomys gapperi, 2 different Microtis longicaudus, and 5 different Eutamius amoenus. Both C. gapperi and E. amoenus are typically found in cold forests and woodlands (Nowak 1991). Of the adult $C$. gapperi we captured, 2 were females and 7 were males.

In total, there were 1179 trap-nights, 20 captures and 9 recaptures on the lodgepole pine plot. So, trapping success was $3.8 \%$. Of the 13 C. gapperi captured, only 4 individuals were recaptured a total of 8 times. The low number of recaptures meant we could not estimate population numbers of $C$. gapperi by either Jolly Seber or with a regression slope (we tested the regression slope up to $\mathrm{p} \leq 0.2$ ). One of the five $E$. amoenus was recaptured. Densities of $C$. gapperi fluctuate widely from season to season and year to year and range from 2 to 74 per ha (Nowak 1991).

When walking the one hectare plot to search for sign, we recorded the following data: 4 red squirrel (Tamiasciurus hudsonicus) middens, 13 large ungulate beds, 1 pocket gopher winter cast, 5 fresh pocket gopher mounds, 31 piles of elk scat, 8 piles of moose scat, 1 deer scat, 1 coyote scat, and 1 pine marten (Martes americana) scat.

From 4 August to 20 August, we trapped an area of mixed grasses and forbs, classed as an M3 by Debinski et al. (1996). The plot is located near Lozier hill and the UTMs are E 538750 and N 856400 . In total, there were 2010 trap-nights with 47 individuals captured and 29 recaptures. Trapping success was therefore $3.8 \%$. By species, we captured 21 Microtis (we believe $8 \mathrm{M}$. montanus and $13 \mathrm{M}$. pennsyvannicus) with 7 individuals recaptured 11 times. We captured 21 Peromyscous maniculatus with 7 individuals recaptured 15 times. Three Thomomys talpoides were captured, with one 
recapture, and 2 Zapus princeps were captured (both recaptured once).

Of the captured adult Microtis, 4 were females (2 lactating) and 6 were males. Of the captured adult $P$. maniculatus, 1 was a male and 9 were females (4 lactating). No populations of Microtis or $P$. maniculatus could be estimated via regression (testing up to $\mathrm{p} \leq 0.2$ ). Using the Jolly Seber model, we estimated a population of 55 Microtis (S.E. $=67$ ) on the 1 ha grid. The Jolly Seber model estimated a population of $24 P$. maniculatus $(\mathrm{S} . \mathrm{E} .=19)$ on the same grid. Combining the capturerecapture data for both Microtis and P. maniculatus, we estimated a population of 93 small rodents (S.E. = 77). With a small sample size of 4 captures, two adult female $P$. maniculatus used an area of $50 \mathrm{~m}^{2}$ and $2,400 \mathrm{~m}^{2}$.

Microtis densities vary greatly from year to year, and M. pennsylvanicus may cycle every three or four years (Nowak 1991). Normal densities for $M$. pennsylvanicus are between 37 and 117 per ha, but may reach 1000 per ha (Nowak 1991). Pinter (pers. com.) suggests that $M$. montanus is dominant over $M$. pennsylvanicus, and M. pennsylvanicus only reaches high numbers when M. montanus is low (Nowak 1991).

When walking the one hectare plot of mixed grasses and forbs, we recorded the following data: 462 fresh pocket gopher mounds, 93 pocket gopher winter-casts, 283 mouse/vole holes, 101 vole runways, 2 vole nests, 134 piles of elk scat, 2 deer scat, 2 coyote scat, 1 elk bed, and 3 anthills.

From 4 August until 12 August, we trapped a grid located in a sedge-grass damp meadow (classified as an M2 by Debinski et al. 1996). In total, there were 1085 trap-nights with 64 captures and 24 recaptures of Microtis. So, trap success was $8.8 \%$. Of the 64 Microtis, we believe that 54 were $M$. pennsylvanicus and 10 were $M$. montanus (pending the upcoming tests of the method to differentiate the species). Fifteen of the $54 \mathrm{M}$. pennsylvanicus and 3 of the $10 \mathrm{M}$. montanus were recaptured during the trapping session. Of captured adults, 23 were females (12 lactating) and 17 were males.

Using the Jolly Seber model we estimate two population sizes for Microtis on the 1 ha grid located in the grass-sedge damp meadow. The low estimate was 69 individuals (S.E. $=48$ ) and the high was 136 individuals (S.E. = 124). Because we captured 64 individuals and only recaptured 18 of those animals, we place more confidence in the higher estimate.

When walking the 1 ha plot of grass-sedge damp meadow, we recorded the following data: 24 vole holes, 12 vole runways, 2 vole nests, 9 moose scats, 2 elk scats, 1 deer scat, 1 coyote scat, 1 fox scat, 1 pocket gopher winter-cast, and 1 anthill. The lack of scat and vole holes may be misleading if one is looking across different habitat types, as the wetness of this grid will eliminate scat more rapidly than in drier areas. And, although there were few holes deeper than the length of a finger, there are a myriad of ways to get beneath patches of moss.

From 15 August until 23 August, we trapped a 1 ha grid located in a sedge-grass swamp, classified as M1 by Debinski et al. (1996). In total, there were 1190 trap-nights, and 47 individual Microtis (we believe all $M$. pennsylvanicus) were captured with 14 individuals recaptured a total of 32 times. So, in this habitat, trap success was $6.6 \%$.

Using the Jolly Seber model we estimate two population sizes for Microtis on the 1 ha grid located in the grass-sedge swamp. The low estimate was 61 individuals (S.E. $=46)$ and the high was 78 individuals (S.E. $=66$ ). Of the captured Microtis, 20 were adult females and 15 of those 20 were lactating. Fifteen captured animals were adult males, and 12 were juveniles ( 9 male and 3 female). Two adult animals were captured 5 times. The area used by the adult female was $400 \mathrm{~m}^{2}$ while the adult male covered $1008 \mathrm{~m}^{2}$.

When walking the 1 ha plot of grass-sedge swamp, we recorded the following data: 2 moose beds, 1 coyote scat, 6 vole nests, and 16 vole holes. From these preliminary data, there appear to be distinct species associated with vegetation type. For example, red backed vole and chipmunks were trapped only in lodgepole pine plots. In addition, sign representing red squirrels and pine marten were unique to this area. Only meadow voles and mountain voles were found in the two most mesic meadows (M1 and M2). The highest rodent density of all plots was in the M2 meadow with 136 microtus $\mathrm{sp} /$ ha followed by the M1 meadow with 78 microtus $\mathrm{sp} /$ ha. The greatest rodent diversity was found in the M3 meadow where trapping revealed deer mice, meadow and mountain voles, pocket gophers and jumping mice with estimates of 55 microtus $\mathrm{sp} /$ ha and 24 peromyscus / ha. The xeric M6 meadow only presented trapping success for a single species, the deer mouse at a density of between 12-17/ ha. However, sign for badgers and bison were unique 
only to this area. Elk sign was greatest in the M3 followed by M6 and lodgepole pine plots, but absent from view in the M1 and M2 meadows. Moose sign was highest in the M2 plot followed by the lodgepole pine and M1 plots. Pocket gopher sign was most abundant in the M3 meadow followed by the M6 and lodgepole pine plots and were absent from the mesic M1 and M2 meadows. From this data, presence or absence and relative abundance of small mammals can be predicted based upon vegetation type.

In year 2000, we will expand our efforts, trapping 7 habitat types with 2 replicates in each type. The 1999 data will be beneficial, but only in the context of repeated sampling over time to demonstrate trends that can be correlated with environmental changes.

\section{Literature Cited}

Beauvais, G.P. and S.W. Buskirk. 1999. Modifying estimates of sampling effort to account for sprung traps. Wildlife Society Bulletin 27: 39-43.

Bergerud, A. T. 1988. Caribou, wolves and man. Trends in Ecology and Evolution 3: 68-72.

Burnham, K.P., D.R. Anderson, and J.L. Laake. 1980. Estimation of Density from Line Sampling of Biological Populations. Wildlife Monograph Vol. 72.

Caughley, G. 1977. Analysis of vertebrate populations. John Wiley and Sons, New York, New York.

Clark, T.W. and M.R. Stromberg. 1987. Mammals in Wyoming. University of Kansas Museum of Natural History, Lawrence, Kansas, USA.

Crabtree, R.L and J.W. Sheldon. 1999. Coyotes and canid coexistence in Yellowstone. Pp. 127163 in Carnivores in ecosystems: The Yellowstone experience. (Eds.) T.W. Clark, A.P. Curlee, S.C. Minta, and P.M. Kareiva. Yale University Press, New Haven, Connecticut.

Crooks, K. and M. Soulé. 1999. In a fragmented system. Nature 400: 563-566.
Debinski, D.M., K. Kindscher, M.E. Jakubauskus. 1996. Biodiversity and Remotely Sensed Habitat Types: A Comparison of Montane Meadows in the Gallatin Range, MT and in Grand Teton National Park, WY. University of Wyoming, National Park Service Research Center $20^{\text {th }}$ Annual Report, pp. 4549.

Dobson, A.P. and R.M. May. 1986. Disease and Conservation pp. 345-365 in Conservation Biology: The Science of Scarcity and Diversity. Sinauer Associates, Sunderland, Massachusetts, USA.

Erlinge, S., G. Goransson, G. Hogstedt, G. Jansson, O. Liberg, J. Loman, I.N. Nilsson, T. von Schantz, and M. Silvan. 1984. Can vertebrate predators regulate their prey? American Naturalist 123: 125-154.

Erlinge S., G. Göransson, G. Högstedt, G. Jansson, O. Liberg, J. Loman, I. N. Nilsson, T. von Schantz and M. Sylvén. 1988. More thoughts on vertebrate predator regulation of prey. The American Naturalist 132: 148154.

Estes, J. A. 1996. Carnivores and ecosystem management. Wildlife Society Bulletin 24: 390-396.

Hatter, I. and D. W. Janz. 1994. The apparent demographic changes in black-tailed deer associated with wolf control in nothern Vancouver Island, Canada. Canadian Journal of Zoology 72: 878-884.

Henke, S.E. and F.C. Bryant. 1999. Effects of coyote removal on the faunal community in west Texas. Journal of Wildlife Management 63: 1066-1081.

Hoogland, J.L. 1995. The black-tailed prairie dog: Social life of a burrowing mammal. University of Chicago Press, Chicago, Illinois.

Hunter M.D. and P.W. Price. 1992. Playing chutes and ladders: Heterogeneity and the relative roles of bottom-up and top-down forces in natural communities. Ecology 73: 724-732. 
Krebs, C.J., S. Boutin, R. Boonstra, A.R.E. Sinclair, J.N.M. Smith, M.R.T. Dale, and R. Turkington. 1995. Impact of food and predation on the snowshoe hare cycle. Science 269: 1112-1114.

Lancia, R.A., J.D. Nichols, and K.H. Pollock. 1996. Estimating the number of animals in wildlife populations. Pp. 215-253 in Research and Management Techniques for Wildlife and Habitats. Ed. T.A. Bookhout, The Wildlife Society, Bethesda, Maryland.

Mclaren, B. E. and R. O. Peterson. 1994. Wolves, moose and tree rings on Isle Royale. Science 266: 1555-1558.

Messier, F. 1994. Ungulate population models with predation: A case study with the North American moose. Ecology 75(2): 478-488.

Messier, F., and M Crête. 1985. Moose-wolf dynamics and the natural regulation of moose populations. Oecologia 65: 503-512.

Naiman, R. J., G. Pinay, C. A. Johnston and J Pastor. 1994. Beaver influences on the long-term biogeochemical characteristics of boreal forest drainage networks. Ecology 75: 905921.

Noss, R.F. and A. Copperrider. 1994. Saving Nature's Legacy: Protecting and Restoring Biodiversity. Island Press, Covelo, California, USA.

Noss, R.F., M.A. O'Connell, and D.D. Murphy. 1996. The Science of Conservation Planning: Habitat Conservation under the Endangered Species Act. Island Press, Covelo, California, USA.

Nowak, R.M. 1991. Mammals of the world: Fifth edition. John Hopkins University Press, Baltimore Maryland.

Otis, D.L., K.P. Burnham, G.C. White, and D.R. Anderson. 1978. Statistical inference from capture data on closed animal populations. Wildlife Monograph 62.

Pastor, J., R. J. Naiman and B. Dewey. 1988. Moose, microbes and boreal forests. Bioscience 38: 770-777.
Pickett, S.T.A. and P.S. White. 1985. The Ecology of Natural Disturbance and Patch Dynamics. Academic Press, Orlando, Florida, USA.

Pinter, A.J. 1996. Climatic Factors, Reproductive Success and Population Dynamics in the Montane Vole, Microtus montanus. University of Wyoming and the National Park Service Research Center Annual Report, pp. 88-90.

Polis G.A. and D.R. Strong. 1996. Food web complexity and community dynamics. American Naturalist 147: 813-846.

Pollock, M. M., R. J. Naiman, H. E., Erickson, C. A. Johnston, J. Pastor and C. Pinay. 1995. Beaver as engineers: influences on biotic and abiotic characteristics of drainage basins. In: Linking species and ecosystems, C. G. Jones and J. H. Lawton, eds., pp. 117126. Chapman and Hall, New York.

Post, E., R.O. Peterson, N.C. Stenseth, and B.E. McClaren. 1999. Ecosystem consequences of wolf behavioural response to climate. Nature 401: 905-907.

Sinclair, A.R.E. 1991. Science and the practice of wildlife management. Journal of Wildlife Management 55: 767-773.

Smith, D.W., W.G. Brewster, and E.E. Bangs. 1999. Wolves in the Greater Yellowstone Ecosystem: Restoration of a top carnivore in a complex management environment. $\mathrm{Pp}$. 103-125 in Carnivores in ecosystems: The Yellowstone experience. (Eds.) T.W. Clark, A.P. Curlee, S.C. Minta, and P.M. Kareiva. Yale University Press, New Haven, Connecticut.

Soulé, M.E., E.T. Bolger, A.C. Alberts, J. Wright, M. Sorice, and S. Hill. 1988. Reconstructed dynamics of rapid extinctions of chaparrelrequiring birds in urban habitat islands. Conservation Biology 2: 19-28.

Terborgh, J., L. Lopez, J. Tello, D. Yu, and A. R. Bruni. 1997. Transitory states in relaxing land bridge islands. Pp. 256-274 in Tropical forest remnants: ecology, management, and conservation of fragmented communities. W. F. Laurance and R. O. Bierregaard, Jr. (eds.). University of Chicago Press, Chicago, Illinois, USA. 
Terborgh, J., J. Estes, P. Paquet, K. Ralls, D. Boyd, B. Miller, and R. Noss. 1999. Role of top carnivores in regulating terrestrial ecosystems. In press in The Science of Continental Scale Reserve Design. M. Soulé, and J. Terborgh (eds.). Island Press, Covelo, California, USA.

Thompson, W.L., G.C. White, and C. Gowan. 1998. Monitoring Vertebrate Populations. Academic Press, New York, New York, USA.
White, G.C., D.R. Anderson, K.P. Burnham, D.L. Otis. 1982. Capture-recapture and removal methods for sampling closed populations. Los Alamos National Laboratory, LA-8787NERP, Los Alamos, New Mexico. 